$\mathrm{A} \mathrm{J}_{\mathrm{sin}} \mathrm{H}$

Article history :

Received : 18.10 .2014

Revised : 12.11.2014

Accepted : 26.11.2014
Members of the Research Forum

Associated Authors:

${ }^{1}$ Department of Horticulture, Gochar Mahavidalaya, Rampur Maniharan, SAHARANPUR (U.P.) INDIA

${ }^{2}$ Department of Horticulture, C.C.R (P.G.) College, MUZAFFARNAGAR (U.P.) INDIA
Author for correspondence : J.P. SINGH

Department of Horticulture, Gochar Mahavidalaya, Rampur Maniharan, SAHARANPUR (U.P.) INDIA

Email : singhjp2005@yahoo.com
THE ASIAN JOURNAL OF HORTICULTURE

Volume 9 | Issue 2 | Dec., 2014 |459-462

Visit us -www.researchjournal.co.in

\title{
Flowering, fruiting, yield and physical character of fruit of mango cv. DASHEHARI as influenced by pre-harvest foliar spray of nutrients and plant bio-regulators
}

\section{P. CHAUHAN ${ }^{1}$, J.P. SINGH, INDU ARORA ${ }^{1}$ AND R.K. SINGH ${ }^{2}$}

ABSTRACT : The experiment was carried out in the orchard situated in district Saharanpur (U.P.) during the years 2010 and 2011 with an aim to improve the yield and physical characters of mango fruit. The treatments were comprised of mulching, borax @ 0.5 and 1.0\%, potassium sulphate @ 0.5 and $1.0 \%$, calcium chloride @ 0.5 and $1.0 \%$, calcium nitrate @ 0.5 and 1.0\%, GA @ 25ppm and 50 ppm, NAA @ 25ppm and 50 ppm in combination with mulching and water spray without mulching as control. The spray was done three times at different stages during the year 2010 and 2011 which is given below-Ist spray on 15th January (i.e. before flower bud burst), IInd spray on 15th February (i.e. at panicle emergence) and IIIrd spray on 15th April (i.e. after fruit set). The findings of experiment were indicated that the application of borax @ $0.5 \%$ along with mulching was most effective for increasing fruit quality. The shelf life of fruits was significantly increased by the application of growth regulators.

KEY WORDS : Flowering, Fruiting, Yield, Mango, Plant bio-regularos

HOW TO CITE THIS ARTICLE : Chauhan, P., Singh, J.P., Arora, Indu and Singh, R.K. (2014). Flowering, fruiting, yield and physical character of fruit of mango cv. DASHEHARI as influenced by pre-harvest foliar spray of nutrients and plant bio-regulators. Asian J. Hort., 9(2) : 459-462. 